\title{
ASSESSMENT OF COMPONENTS OF COMBINATION ABILITY SILVER BLACK FOXES OF DIFFERENT LINES BY FERTILITY
}

Petrash V. S., Institute of Animal Science of NAAS.

Improving the efficiency of breeding for fox's reproductive qualities advasing is associated with the selection of individuals with certain economically useful traits and evaluated for their ability to transfer and fix ones in subsequent generations. A combining ability of parental lines determination, as well as individual characteristics of animals, is paramount. The factors characterizing the contribution of each parents, as well as their combination with each other in the formation of the descendant's productive potential, are the combinational capacity components, which are disclosed on the basic fur animal farming of Kharkiv region.

The analysis of six lines of the breeding core of silver-black foxes was carried out and the general and specific combining ability of maternal and paternal forms were determined by fertility. The probable influence of the specific combining ability of the combinations to the studied parameter was established, which allowed a clear differentiation of the lines according to the level of fertility: improvers, neutral and degraders. In addition to the obvious fundamental value, the information obtained is also important practical point of view. In particular, it was concluded that it is advisable to use individual representatives of the lines, as well as the most promising options for combinations of parental pairs. Using components of combining ability, outsiders are defined, which should be excluded from the further selection process. The actual research materials illustrate the results of dispersive analysis of differences in fertility of females, average fertility rates of combinations of maternal and paternal lines, combination capacity of lines, effects of general combining ability, constants and variants of specific combination ability of linear foxes.

Key words: silver-black foxes, reproductive ability, combining ability, lines, fertility.

DOI 10.32900/2312-8402-2019-121-198-206

УДК 636.2.03:637.5'62

\section{ОСОБЛИВОСТІ СКЛАДУ АНАТОМІЧНИХ ЧАСТИН ТІЛА ТА М'ЯСНОСТІ КОРІВ ЗНАМ'ЯНСЬКОГО ТИПУ ПОЛІСЬКОЇ ПОРОДИ РІЗНИХ ЛІНІЙ}

\author{
Попова В. О., к. с.-Г. Н., доцент \\ Васильсва Ю. О., к. с.-Г. Н., доцент \\ Цуканова М. О., асп. \\ Боднарчук І. М., ст. викладач \\ Харківська державна зооветеринарна академія
}

М'ясо в харчуванні людини є основним джерелом біологічно повноцінного білка. Забезпечення білком завжди було актуальним питанням агропромислового комплексу, яке загострилось нині, так як загальна науково обтрунтована норма його споживання на душу населення в Украӥні з кожним роком стрімко знижується $i$ становить 54,6 кг проти 80 кг. Саме тому підвищення виробництва і покращення якості м'ясної продукиії, зокрема, яловичини, у тому числі одержаної й від м'ясної худоби, $\epsilon$ важливим народногосподарським завданням. Успішне вирішення ијього завдання можливе за впровадження науково- 
обтрунтованої системи племінної роботи, основним елементом якої є розведення за лініями.

Знам'янський тип поліської породи створено в 2009 роичі. Порода представлена лініями Радиста 113, Мазуна 6 та Дарованого 400, крім того в господарствах Украӥни наявне поголів'я й інших ліній, які не ввійшли до остаточного складу породи.

У рамках виконання досліджень сформовано 4 групи повновікових корів знам'янського типу, по 10 голів у кожній: I - контрольна (тварини, які не ввійшли до дослідних груп), II дослідна - лінії Мазуна 6; III дослідна - лінії Радиста 113; IV дослідна - лінії Дарованого 400. Для проведення забою з кожної групи відібрали по 3 голови. Піддослідних тварин усіх груп утримували за умов класичної технологї м'ясного скотарства. Встановлено, щзо за масою поперекової $i$ тазостегнової частини, які є найбільш цінними, значну перевагу мали корови лінії Радиста 113. Найвищзі показники відносної $і$ абсолютної маси шийної частини туші були у корів груп ліній Мазуна 6 та Дарованого 400. Тоді як за масою охолодженої напівтуші корови III групи значно перевершували контрольних аналогів, а також представниць II групи. Корови нащадки Дарованого 400 займали проміжне місие. Аналогічну залежність відмічали й за кількістю м'яса першого татунку. Дегустащійний аналіз свідчить про те, щзо м'ясо і бульйон усіх піддослідних тварин характеризувалися доброю якістю і одержали високу оцінку.

Ключові слова: корови, знам'янський тип поліської породи, лінія, якість м'яса, анатомічні частини тулубу, м'ясо, бульйон.

Яловичина, особливо від спеціалізованих м'ясних порід, є дуже цінною тваринницькою сировиною. Їй властиві високі смакові якості, збалансований дієтичний склад та постійний попит у споживачів. Спеціалізована м'ясна худоба $€$ джерелом найбільш високоякісної яловичини, однак в силу багатьох чинників іï чисельність із року в рік залишається незначною. Незважаючи на це в країні $€$ власні м'ясні породи та певна кількість тварин закордонної селекції [1].

Одним із пріоритетів оцінки великої рогатої худоби м'ясного напряму можна виокремити показники власної м'ясної продуктивності, бо саме вони є критерієм конкурентоспроможності для будь якої м'ясної породи. М'ясна худоба має властиві їй особливості анатомічної будови тіла, i, як наслідок чого більший вихід їстівних частин туші. Організм тварини під час росту та розвитку зазнає низки змін, які безпосередньо впливають на його подальшу м'ясну продуктивність. У цілому, рівень м'ясної продуктивності та якості м'яса залежить від багатьох чинників, однак всі вони можуть бути об'єднанні у три основні групи: спадкові характеристики; фізіологічний стан тварини, умови довкілля [2-4].

За розведення сучасної м'ясної худоби, під впливом попиту на пісну яловичину, намагаються одержати туші з високим вмістом м'язової тканини, оптимальною кількістю жиру та мінімальною кількістю кісток. Ці характеристики намагаються закріпити генетично, однак нерідко на кінцеві результати вирощування негативно впливають технологічні умови вирощування тварин $[5,6]$.

Анатомічна будова тіла великої рогатої худоби чітко вказує на напрям іiі продуктивності. Дослідження м'ясної продуктивності спеціалізованої м'ясної худоби не можливо без вивчення особливостей анатомічних частин та м'ясності туш. Під час обрання тієї чи іншої технології слід брати до уваги доцільність саме обраного варіанту. Високі результати діяльності, як свідчить практика, можна до- 
сягти на тих фермах, де застосовують прості, дешеві і в той же час надійні і ефективні технологічні засоби механізації та ведення галузі в цілому $[7,8]$.

Знам'янський тип поліської породи було створено у 2009 році. Структурними його одиницями на етапі апробації стали заводські лінії Радиста 113, Мазуна 6 і Дарованого 400, крім того в господарствах України наявне поголів'я й інших ліній знам'янського типу, які не увійшли до остаточного складу породи, однак використовуються в подальшому її удосконаленні $[7,9,10]$.

Отже, виявлення особливостей складу анатомічних частин тіла та м'ясності у корів знам'янського типу поліської породи різних ліній за умов традиційної технології ведення м'ясного скотарства $є$ актуальним питанням, що вимагає подальшого вивчення.

Мета роботи - дослідити основні показники якості м'яса, одержаного від корів різних ліній знам'янського типу поліської м'ясної породи та розробити пропозиції щодо використання тварин окремих ліній у подальшій роботі з типом.

Матеріал та методи досліджень Об'єктом досліджень - повновікові корови різних ліній знам'янського типу поліської м'ясної породи, яких утримували у виробничих умовах агрофірми «Колос» Знам'янського району Кіровоградської області.

У рамках досліджень за принципом аналогів сформували 4 групи тварин, по 10 голів у кожній: I - контрольна це тварини, які не увійшли до дослідних ліній, II дослідна - лінія Мазуна 6; III дослідна - лінія Радиста 113; IV дослідна лінія Дарованого 400. Тварин утримували за традиційною технологією м'ясного скотарства: влітку на природних пасовищах, взимку - на вигульно-кормовому майданчику з вітрозахисними стінами з тюків соломи.

Для проведення забою 3 кожної групи відібрали по 3 голови. Контрольний забій здійснювали за загальноприйнятими методиками. Під час виконання досліджень застосовували інструментальні, розрахункові, лабораторні, статистичні методи. Вивчення м'ясних якостей окремих частин тіла проводили на 3-х головах 3 кожної лінії. Розпилені півтуші зважували після охолодження і праву півтушу піддавали обваловуванню, при цьому iї розподіляли на шийну плечелопаткову, спиннореберну поперекову та тазостегнову частини. Відносний вихід цих частин туш розраховували до абсолютної маси охолодженої туші. Оцінку якості м'яса i бульйону виконували шляхом дегустації.

Цифрові дані, одержані у досліді, опрацьовували за використання програми Microsoft Exel. Результати середніх значень вважали статистично вірогідними при * - Р>0,95, **- $>>0,99, * * *-\mathrm{P}>0,999$.

Результати досліджень. М'ясна продуктивність великої рогатої худоби визначається сумарним показником росту і розвитку окремих частин тіла. Вплив кожної частини на загальну м'ясність різний і залежить від іiі біологічної значущості в організмі. Розвиток окремих відрубів туш піддослідних тварин наведено в табл. 1.

Представлені у таблиці результати свідчать, що за морфологічним складом анатомічних частин туш піддослідних корів спостерігали значні відмінності. Зокрема, найвищу, серед дослідних груп, відносну і абсолютну масу шийної частини туші було одержано від корів груп Мазуна 6 та Дарованого 400, найменшу - від нащадків Радиста 113. Абсолютна маса плечелопаткової частини туші у потомків бугая-плідника Радиста 113 перебільшувала ровесниць, які не увійшли до дослідних ліній на 5,6 кг (10,4 \%), лінію Мазуна 6 на 4,5 кг (8,3 \%) та Дарованого 400 на 2,2 кг $(4,1 \%)$. 
Абсолютна і відносна маса окремих анатомічних частин туш корів $\left(\bar{X}_{ \pm} S \bar{x}_{)}\right.$

\begin{tabular}{|l|c|c|c|c|}
\hline \multirow{2}{*}{ Частина туші } & \multicolumn{4}{|c|}{ Група (n=3) } \\
\cline { 2 - 5 } & $\begin{array}{c}\text { II } \\
\text { контрольна }\end{array}$ & $\begin{array}{c}\text { III } \\
\text { дослідна }\end{array}$ & $\begin{array}{c}\text { IV } \\
\text { дослідна }\end{array}$ \\
\hline \multicolumn{5}{|c|}{ Абсолютна маса, кг } \\
\hline Шийна & $28,3 \pm 0,93$ & $31,4 \pm 0,54 *$ & $27,1 \pm 0,81$ & $30,9 \pm 0,84$ \\
\hline Плечелопаткова & $48,3 \pm 0,52$ & $49,4 \pm 0,52$ & $53,9 \pm 0,53 * *$ & $51,7 \pm 0,97 *$ \\
\hline Спинореберна & $81,4 \pm 0,98$ & $86,2 \pm 0,75^{*}$ & $96,5 \pm 0,52 * * *$ & $89,3 \pm 0,98^{* *}$ \\
\hline Поперекова & $30,0 \pm 0,58$ & $36,4 \pm 0,52^{* *}$ & $40,3 \pm 0,90^{* * *}$ & $35,4 \pm 0,79^{* *}$ \\
\hline Тазостегнова & $102,7 \pm 0,67$ & $106,6 \pm 0,71^{*}$ & $117,5 \pm 0,62^{* * *}$ & $113,5 \pm 0,61 * * *$ \\
\hline \multicolumn{5}{|c|}{ Відносна маса,\% } \\
\hline Шийна & 9,7 & 10,1 & 8,0 & 9,6 \\
\hline Плечелопаткова & 16,6 & 15,9 & 16,0 & 16,1 \\
\hline Спинореберна & 28,0 & 27,8 & 28,8 & 27,9 \\
\hline Поперекова & 10,3 & 11,8 & 12,0 & 11,0 \\
\hline Тазостегнова & 35,4 & 34,4 & 35,0 & 35,4 \\
\hline
\end{tabular}

Примітка. *-P>0,95, **-P>0,99, ***-P>0,999 вірогідність різниці до контрольної групи

За масою поперекової та тазостегнової частин, які є найціннішими, значну перевагу над тваринами мали також корови-нащадки Радиста 113, відповідно над тваринами, які не увійшли до дослідних ліній перевага становила 10,3 кг та 14,8 кг, над тваринами лінії Мазуна 6 - на 3,9 кг та 10,9 кг, Дарованого 400 - на 4,9 кг та 4,0 кг.

Гатунковий склад туші - об’єктивний показник м'ясної продуктивності худоби і один із основних чинників, які впливають на реалізаційну ціну яловичини. Для визначення вмісту окремих гатунків м'яса в півтушах провели обваловування (табл. 2).

Таблиия 2

Гатунковий склад півтуш корів піддослідних груп

\begin{tabular}{|c|c|c|c|c|}
\hline \multirow[b]{2}{*}{ Показник } & \multicolumn{4}{|c|}{ Група $(n=3)$} \\
\hline & $\begin{array}{c}\text { I } \\
\text { контрольна }\end{array}$ & $\begin{array}{c}\text { II } \\
\text { дослідна }\end{array}$ & $\begin{array}{c}\text { III } \\
\text { дослідна }\end{array}$ & $\begin{array}{c}\text { IV } \\
\text { дослідна }\end{array}$ \\
\hline $\begin{array}{l}\text { Маса охолодженої } \\
\text { півтуші, кг: }\end{array}$ & $145,4 \pm 1,37$ & $155,1 \pm 0,83 * *$ & $167,9 \pm 1,57 * * *$ & $160,2 \pm 0,86^{* * * *}$ \\
\hline $\begin{array}{l}\text { У тому числі } \\
\text { I гатунку, кг }\end{array}$ & $116,5 \pm 0,67$ & $126,6 \pm 0,83 * * *$ & $141,3 \pm 0,77 * * *$ & $132,6 \pm 1,73 * * *$ \\
\hline$\%$ & 80,1 & 81,6 & 84,2 & 82,8 \\
\hline II гатунку, кг & $17,4 \pm 0,58$ & $18,8 \pm 0,38$ & $18,7 \pm 0,83$ & $18,9 \pm 0,36$ \\
\hline$\%$ & 12,0 & 12,1 & 11,1 & 11,8 \\
\hline III гатунку, кг & $11,5 \pm 0,31$ & $9,7 \pm 0,58$ & $7,9 \pm 0,21$ & $8,7 \pm 0,71$ \\
\hline$\%$ & 7,9 & 6,3 & 4,7 & 5,4 \\
\hline
\end{tabular}

Дані таблиці 2 свідчать, що за показником маси охолодженої півтуші корови III групи значно переважали контрольних аналогів, а також представниць 
II групи. Корови-нащадки Дарованого 400 займали проміжне місце. Аналогічний груповий розподіл спостерігався й за кількістю м'яса першого гатунку. Разом із тим, найбільшу перевагу за цим показником мали корови породної групи Радиста 113. Різниця між ними та аналогами, які не увійшли до дослідних ліній була максимальною і становила 24,8 кг або 21,3 \% (Р>0,999).

Отже, найбільша відмінність за масою півтуш і виходом м'яса першого гатунку виявлена на користь корів-нащадків Радиста 113. Це свідчить, про їх здатність досягати високих забійних кондицій і якості туш.

Дегустаційна оцінка це післязабійний показник, що характеризує харчові якості м'ясної сировини. Вона залежить від міри задоволеннями смакових відчуттів споживача і проводиться шляхом дегустації бульйону, вареного та смаженого м'яса. Аромат, смак, ніжність, соковитість, колір визначають кулінарну цінність м'яса. У рамках проведеного досліду було здійснено дегустаційну оцінку м'яса, одержаного від піддослідних корів, матеріали якої наведено у табл. 3.

Результати дегустаційного аналізу свідчать, що м'ясо та бульйон від усіх піддослідних тварин мали високу бальну оцінку. Суттєвої різниці між групами за досліджуваними показниками не встановлено. Варене та смажене м'ясо було ніжним, ароматним, з гарним кольором та смаком. М'ясний бульйон із м'яса відзначався приємним специфічним ароматом, прозорістю, жирові кульки рівномірно розподілялися на його поверхні. Можна стверджувати, що, м'ясна сировина тварин знам'янськкого типу поліської м'ясної породи характеризується високими органолептичними показниками м'ясної сировини.

Отже, розведення знам'янського типу поліської породи в умовах класичної технології м'ясного скотарства дає змогу отримувати високоякісні туші з оптимальною масою окремих анатомічних частин, високим виходом м'яса першого гатунку та відмінними дегустаційними характеристиками.

Таблиия 3

Органолептична оцінка якості м'яса і м'ясного бульйону, бали

\begin{tabular}{|l|c|c|c|c|}
\hline \multirow{2}{*}{ Показник } & \multicolumn{4}{|c|}{ Група (n=3) } \\
\cline { 2 - 5 } & $\begin{array}{c}\text { I } \\
\text { контрольна }\end{array}$ & $\begin{array}{c}\text { II } \\
\text { дослідна }\end{array}$ & $\begin{array}{c}\text { III } \\
\text { дослідна }\end{array}$ & $\begin{array}{c}\text { IV } \\
\text { дослідна }\end{array}$ \\
\hline \multicolumn{5}{|c|}{ М'ясо варене (із макс. 5) } \\
\hline Аромат & $4,86 \pm 0,03$ & $4,87 \pm 0,08$ & $4,96 \pm 0,02$ & $4,92 \pm 0,03$ \\
\hline Смак & $4,79 \pm 0,09$ & $4,90 \pm 0,03$ & $4,88 \pm 0,05$ & $4,96 \pm 0,01$ \\
\hline Ніжність & $4,80 \pm 0,08$ & $4,85 \pm 0,02$ & $4,78 \pm 0,01$ & $4,92 \pm 0,01$ \\
\hline Соковитість & $4,85 \pm 0,02$ & $4,90 \pm 0,04$ & $4,86 \pm 0,05$ & $4,88 \pm 0,06$ \\
\hline \multicolumn{5}{|c|}{ М'ясо смажене (із макс. 5) } \\
\hline Аромат & $4,86 \pm 0,03$ & $4,92 \pm 0,02$ & $4,87 \pm 0,02$ & $4,94 \pm 0,01$ \\
\hline Смак & $4,84 \pm 0,02$ & $4,87 \pm 0,02$ & $4,85 \pm 0,03$ & $4,86 \pm 0,04$ \\
\hline Ніжність & $4,92 \pm 0,02$ & $4,91 \pm 0,04$ & $4,89 \pm 0,03$ & $4,91 \pm 0,04$ \\
\hline Соковитість & $4,84 \pm 0,02$ & $4,85 \pm 0,02$ & $4,88 \pm 0,03$ & $4,91 \pm 0,03$ \\
\hline \multicolumn{5}{|c|}{ М'ясний бульйон (із макс. 5) } \\
\hline Смак і аромат & $4,73 \pm 0,03$ & $4,66 \pm 0,03$ & $4,83 \pm 0,04$ & $4,68 \pm 0,06$ \\
\hline Прозорість і колір & $4,66 \pm 0,03$ & $4,54 \pm 0,02$ & $4,65 \pm 0,02$ & $4,62 \pm 0,01$ \\
\hline Міцність & $4,61 \pm 0,02$ & $4,72 \pm 0,03$ & $4,68 \pm 0,03$ & $4,78 \pm 0,02$ \\
\hline
\end{tabular}

За подальшої роботи з типом, особливу увагу слід приділяти селекційній роботі спрямованій на збільшення відсотку таких цінних відрубів як поперекового 
та тазостегнового за загального збільшення маси туші. У розрізі типу необхідно більш широко використовувати тварин лінії Радиста 113, як такої що найбільш відповідає вимогам до бажаного типу м'ясної худоби.

\section{Висновки:}

1. Встановлено, що тварини усіх піддослідних генотипів мали оптимальну масу окремих анатомічних частин в туші та гатунковий склад м'яса. Дегустаційна оцінка виявила високі смакові характеристики як м'яса, так і бульйону.

2. Доведено, що серед досліджених генотипів за комплексом ознак якості м’яса найкращими виявились нащадки бугая Радиста 113.

\section{Бібліографічний список}

1. Власенко В. В. Сучасний стан та проблеми виробництва і споживання м'яса населенням України / В. В. Власенко, I .В. Левицька // Аграрна наука та харчові технології. - 2017. - Вип. 1(95). - С. 178-184.

2. Прудніков В. Г. Проблеми селекційного процесу в м'ясному скотарстві на сучасному етапі / В. Г. Прудніков, В. О. Попова, М. О. Цуканова // Аграрна наука та освіта в умовах Свроінтеграції : тези доповідей матеріалів міжнар. наук.практ. конф. - Кам'янець Подільський, 2018. - С. 270-272.

3. Тимченко Л. О. Спеціалізоване м'ясне скотарство як стратегічна галузь / Л. О. Тимченко // Вісник аграрної науки. - 2015. - № 1. - С. 39-45

4. Petrovic Z. Meat Production and Consumption: Environmental Consequences / Z. Petrovic, V. Djordjevic, D. Milicevic // Procedia Food Science. - 2015. - № 5. C. 235-238. doi: 10.1016/j.profoo.2015.09.041

5. М'ясна продуктивність великої рогатої худоби : монографія / О. І. Колісник А. М. Угнівенко, Т. А., Антонюк, В. Г. Прудніков. - Київ : ЦП «Компринт», 2018. - 429 с.

6. Сучасні аспекти селекції і відтворення вітчизняних м'ясних порід / Ю В Вдовиченко, М. П. Демчук, Л. О. Дєдова, В. М. Вишневський // Сучасні проблеми селекції, розведення та гігієни тварин : зб. наук. пр. Вінницького нац. унту. - Вінниця, 2011. - № 9 (49). - С. 76-80.

7. Попова В. О. Хозяйственно-биологические особенности коров конечных генотипов создаваемого знаменского типа южной породы : автореф. дис... канд. с -х наук : 06.02.04 „частная зоотехния, технология производства продуктов животноводства" / В. О. Попова. - Курск, 2005. - 24 с.

8. Приступа В. Н. Мясная продуктивность и качество мясного сырья животных калмыцкой породы новых заводских линий / В. Н. Приступа // Теория и практика переработки мяса. - 2017. - № 2. - С. 69-79.

9. Wickham B. A new international infrastructure for beef cattle breeding / B. Wickham, J. Dürr // Animal Frontiers. - 2011. - № 1. - C. 53-59. doi:10.2527/af.2011-0019

10. Попова В. О. Якісна характеристика м'яса тварин знам'янського типу поліської породи / В. О. Попова, Ю. В. Коломієць, А. Л. Леппа // Аграрна наука та харчові технології / Вінницький нац. аграр. ун-т. - Вінниця, 2017. - № 2 (96). C. 225-229.

\section{References}

1. Vlasenko, V. V., \& Levytska, I. V. (2017). Suchasnyi stan ta problemy vyrobnytstva i spozhyvannia m'iasa naselenniam Ukrainy. [Modern state and problems of production and consumption of meat to the populations of Ukraine] Ahrarna nauka ta 
kharchovi tekhnolohii - Agrarian science and food technologies, 95, 178-184 [in Ukrainian].

2. Prudnikov, V., \& Popova, V., Tsukanova M. (2018). Problemy selektsiinoho protsesu v m'iasnomu skotarstvi na suchasnomu etapi [Problems of plant-breeding process are in the meat cattle breeding on the modern stage]. Materialy mizhnarodnoi' naukovo-praktychnoi' konferencii' «Ahrarna nauka ta osvita v umovakh Yevrointehratsii»Materials of the international scientific-practical conference "Agrarian Science and Education in the Conditions of European Integration», (pp. 270-272). Kam'janec' Podil's'kyj [in Ukrainian].

3. Tymchenko, L. O. (2015). Spetsializovane m'iasne skotarstvo yak stratehichna haluz. [Specialized meat cattle breeding as a strategic branch]. Visnyk ahrarnoi nauky - Bulletin of Agrarian Science, 39-45 [in Ukrainian].

4. Petrovic, Z., \& Djordjevic, V., Milicevic, D., et al (2015). Meat Production and Consumption: Environmental Consequences. Procedia Food Science, 5, 235-238. doi: 10.1016/j.profoo.2015.09.041

5. Kolisnyk, O. I., \& Uhnivenko, A. M., .Antoniuk, T. A., \& Prudnikov, V. H. (2018). M'iasna produktyvnist velykoi rohatoi khudoby - Meat productivity of cattle. Kyiv: TsP «Komprynt» [in Ukrainian].

6. Vdovychenko, Y. V., \& Demchuk, M. P., Diedova, L. O., Vyshnevskyi, V. M. (2011). Modern aspects of breeding and reproduction of domestic meat breeds [Modern aspects of breeding and reproduction of domestic meat breeds]. Suchasni problemy selektsii, rozvedennia ta hihiieny tvaryn - Modern problems of breeding, breeding and animal hygiene. Vinnycja : Vinnycja NAU, 9, 76-80 [in Ukrainian].

7. Popova, V. O. (2005). Xozyajstvenno-biologicheskie osobennosti korov konechny`x genotipov sozdavaemogo znamenskogo tipa yuzhnoj porodi [Economicbiological features of cows of eventual genotypes of the created znamensky type generate south]. Extended abstract of candidate's thesis. Kursk : Kurskaya gosudarstvennaya sel'skoxozyajstvennaya akademiya [in Russian].

8. Pristupa, V. N., \& Kolosov, Y. A., Kolosov, A. Y., Orlova, O. N. (2017). Myasnaya produktivnost` i kachestvo myasnogo sy`r`ya zhivotny`x kalmy`czkoj porody` novy`x zavodskix linij. Teoriya $i$ praktika pererabotki myasa, 2, 69-79. doi: 10.21323/2414-438X-2017-2-2-69-79 (in Russian).

9. Wickham, B., \& Dürr, J. (2011). A new international infrastructure for beef cattle breeding. Animal Frontiers, 1, 53-59. doi:10.2527/af.2011-0019

10. Popova, V. O., \& Kolomiiets, Y. V., Leppa, A. L. (2017). Yakisna kharakterystyka m'iasa tvaryn znam'ianskoho typu polisko yi porody [Quality description of meat of animals of znamensky as Polesye $\ddot{i}$ of breed]. Ahrarna nauka ta kharchovi tekhnolohii - Agrarian science and food technologies. Vinnytsia : Vinnyt NAU, 96, 225-229 [in Ukrainian].

ОСОБЕННОСТИ СОСТАВА АНАТОМИЧЕСКИХ ЧАСТЕЙ ТЕЛА И МЯСНОСТИ КОРОВ ЗНАМЕНСКОГО ТИПА ПОЛЕССКОЙ ПОРОДЫ РАЗНЫХ ЛИНИЙ

Попова В. А., Васильева Ю. А., Цуканова Н. А., Бондарчук И. М., Харьковская государственная зооветеринарная академия, г. Харьков, Украина

Мясо в питании человека является основным источником биологически полноченного белка. Обеспечение белком всегда было актуальным вопросом агропромышленного комплекса, который обострился в настоящее время, так как общая научно обоснованная норма его потребления на душу населения в Украине с 
каждым годом стремительно снижается и составляет 54,6 к2 против 80,0 к2. Именно поэтому повышение производства и улучшения качества мясной продукции, в частности, говядины, в том числе полученной и от мясного скота, является важной народнохозяйственной задачей. Успешное решение этой задачи возможно при внедрении научно-обоснованной системы племенной работы, основным элементом которой является разведение по линиям.

Знаменский тип полесской породы создан в 2009 году. Порода представлена линиями Радиста 113, Мазуна 6 и Дарованого 400, кроме того в хозяйствах Украины имеется поголовье и других линий, которые не вошли в окончательный состав породы.

В рамках выполнения исследований сформированы 4 группы полновозрастных коров знаменского типа, по 10 голов в каждой: I - контрольная (животные, которые не вошли в опытные группь), II опьтнная - линия Мазуна 6; III опытная - линия Радиста 113; IV опьтная - линии Дарованого 400. Для проведения убоя из каждой группы отобрали по 3 головы. Подопьтнных животных всех групп содержали в условиях классической технологии мясного скотоводства. Установлено, что по массе поясничной и тазобедренной части, которые являются наиболее ценными, значительное преимущество имели коровы линии Радиста 113. Самые высокие показатели относительной и абсолютной массы шейной части туши были у коров групп линий Мазуна 6 и Дарованого 400. Тогда как по массе охлажденной полутуши коровы III группь значительно превосходили контрольных аналогов, а также представительнии II группы. Коровы потомки Дарованого 400 занимали промежуточное место. Аналогичную зависимость отмечали и по количеству мяса первого сорта. Дегустационный анализ свидетельствует о том, что мясо и бульон всех подопытных животных характеризовались хорочим качеством и получили высокую оченку.

Ключевые слова: коровы, знаменский тип полесской породы, линия, качество мяса, анатомические части туловища, мясо, бульон.

\section{FEATURES OF THE STRUCTURE OF ANATOMICAL PARTS OF THE BODY AND MEATINESS OF COWS OF THE ZNAMENSKY TYPE POLISKA BREED OF DIFFERENT LINES}

Popova V., Vasylieva Yu., Tsukanova M., Bodnarchuk I., Kharkiv State Zooveterinary Academy, Kharkiv, Ukraine.

Meat in human diet is the main source of biologically complete protein. Protein supply has always been a topical issue of the agro-industrial complex, which has become more acute at present, as the overall scientifically justified norm of its consumption per capita in Ukraine is rapidly decreasing every year and amounts to $54.6 \mathrm{~kg}$ against $80 \mathrm{~kg}$. Therefore, increasing the production and improving the quality of meat products, in particular beef, including beef obtained from beef cattle, is an important national economic task. Successful solution of this problem is possible with the introduction of scientifically based system of tribal work, the main element of which is breeding along the lines.

Znamensky type Poliska breed was created in 2009. The breed is represented by lines of Radyst 113, Mazun 6 and Darovanyy 400, moreover, there are other lines in the farms of the Ukraine, which are not included in the final composition of the breed.

In the framework of the research 4 groups of full-age cows of the Znamensky type were formed with 10 cows in each: I-control (animals that were not included in the experimental groups); II experimental - lines of Mazun 6; III experimental - lines of Radyst 113; IV experimental - lines of Darovanyy 400. Three cows were taken from 
each group for slaughter. The experimental animals of all groups were kept in the conditions of classical technology of beef cattle breeding. It was found out that by the mass of the lumbar and hips, which are the most valuable, the cows lines of Radyst 113 had a significant advantage. The highest relative and absolute masses of the cervical part of the carcass were observed in cows of lines Mazun 6 and Darovanyy 400. Whereas cows of III group significantly surpassed control analogues and representatives of II group by weight of the chilled carcasses. Cows the descendants of Darovanyy 400 were in an intermediate position. A similar dependence was noted for the quantity of meat of the first grade. The tasting analysis shows that the meat and broth of all the experimental animals were of good quality and got high marks.

Key words: cows, Znamensky type of Polissya breed, line, quality meat, anatomical parts of the body, meat, broth.

DOI 10.32900/2312-8402-2019-121-206-217

УДК 636.13.082

\title{
ФОРМУВАННЯ МАТОЧНИХ РОДИН ТА ЇХ РОЛЬ У МІКРОЕВОЛЮЦІЇ УКРАЇНСЬКОЇ ВЕРХОВОЇ ПОРОДИ
}

\author{
Ткачова I. В., Д. с.-Г. Н., с. Н. с.
}

Інститут тваринництва НААН

Метою досліджень було вивченні генеалогічної структури української верхової породи за маточними родинами, щчо формують популяцію, та оцінці їх за комплексом селекційних ознак. Досліджено поголів'я племінних кобил суб'єктів племінної справи з розведення коней української верхової породи $(n=272)$.

У загальній структурі украӥнської верхової породи виділені маточні родини, визначена роль кобил-родоначальниць різних порід у матрилінійну структуру сучасного племінного ядра породи. Проаналізовано еволюцію формування маточного ядра української верхової породи. Структурні одиниці маточного ядра оцінено за комплексом селекційних ознак.

Доведено, щуо у створенні украӥнської верхової породи значний вплив здійснило використання на ранньому етапі формування відтворювального складу коней угорського походження. Значну кількість маточних родин створено на основі угорських порід, до яких належали матері родоначальниць та самі родоначальниці. Аналіз походження кобил - родоначальниць сучасних маточних родин показав, щзо їх родоводи побудовані переважно на тракено-угорських, англо-угорських та англо-тракено-угорських породних комплексах.

На час апробачії української верхової породи було зареєстровано 16 маточних родин, щуо включали від 4 до 21 племінних кобил (табл. 2). Найбільш чисельними були родини Нони, 541 Хохлатки (по 10,4\%), 496 Флангової (9,5\%) та Фарси (9,0\%). Кращими за комплексом ознак були оцінені родини: 86 Інфри I, 266 Аризони, 317 Билини, 89 Канітєлі, 104 Маріщии, Нони, 541 Хохлатки, Фарси, 496 Флангової, Фаворитки.

Встановлено, щуо сучасна структура украӥнської верхової породи включає 23 маточних родини, кількість кобил у яких становить від трьох $і$ більше голів. Найбільш чисельні маточні родини за кількістю продовжувачок: 159 Теми (13,2 \% у маточному складі) та 86 Інфри I (12,5\% у маточному складі). Крім того, у маточному складі кінних заводів також використовуються 29 кобил, які по- 